\title{
Peningkatan Hasil Belajar Unsur Intrinsik Cerpen Melalui Model Pembelajaran Kooperatif Tipe Jigsaw Pada Peserta Didik Kelas IX A4 MTsS Dar-El Hikmah Pekanbaru
}

\author{
Martalena \\ Guru MAN 3 Pekanbaru
}

\begin{tabular}{l}
\hline \hline \multicolumn{1}{c}{ INFO ARTIKEL } \\
\hline Riwayat Artikel: \\
Diterima: $15-04-2020$ \\
Disetujui: $18-04-2020$ \\
\\
\hline Kata kunci: \\
Hasil Belajar \\
Unsur Instrinsik Cerpen \\
Model Pembelajaran Kooperatif \\
Tipe Jigswa
\end{tabular}

\section{Alamat Korespondensi:}

Martelena

Guru MAN 3 Pekanbaru

E-mail: martalena@gmail.com

\begin{abstract}
The purpose of this study is to improve the learning outcomes of the short story intrinsic element through a jigsaw cooperative learning model. The design of this study is Classroom Action Research (CAR). The study was conducted with the aim of increasing the rational stability of the actions taken by educators so that learning outcomes are more optimal. This research was conducted from the end of August to the beginning of September 2017. The research was carried out based on the results of tests on Daily Repetition I, namely on Thursday, July 28, 2017. The subjects of this study were students of Class IX A4 MTsS Dar El Hikmah Pekanbaru. Students of Class IX A4 MTsS Dar El Hikmah Pekanbaru consist of women. The instrument used to collect research data was observation sheets, tests and documentation analyzed descriptively qualitatively and quantitatively, both individually and classically. The results showed the use of Jigsaw cooperative learning models can also improve learning outcomes of understanding the intrinsic elements of the short story. This can be seen from the test results obtained by students in each cycle. In the first cycle students test results increased $33.33 \%$, while in the second cycle increased $11.11 \%$. So in each cycle there is a significant increase in learning outcomes.
\end{abstract}

ABSTRAK

Abstrak: Tujuan penelitian ini adalah meningkatkan hasil belajar unsur intrinsik cerpen melalui model pembelajaran kooperatif tipe jigsaw. Rancangan penelitian ini adalah Penelitian Tindakan Kelas (PTK). Penelitian dilaksanakan dengan tujuan untuk meningkatkan kemantapan rasional dari tindakan-tindakan yang dilakukan oleh pendidik sehingga hasil belajar lebih maksimal. Penelitian ini dilaksanakan dari akhir Agustus sampai awal September 2017. Penelitian dilaksanakan berdasarkan hasil tes pada Ulangan Harian I, yaitu pada Kamis 28 Juli 2017. Subjek penelitian ini adalah peserta didik Kelas IX A4 MTsS Dar El Hikmah Pekanbaru. Peserta didik Kelas IX A4 MTsS Dar El Hikmah Pekanbaru terdiri atas perempuan. Instrumen yang digunakan untuk mengumpulkan data penelitian adalah lembar observasi, tes, dan dokumentasi yang dianalisis secara deskriptif kualitatif dan kuantitatif, baik secara individu maupun klasikal. Hasil penelitian menunjukkan pengunaan model pembelajaran kooperatif tipe Jigsaw juga dapat meningkatkan hasil pembelajaran pemahaman unsur intrinsik cerpen. Hal itu dapat dilihat dari hasil tes yang diperoleh peserta didik pada setiap siklus. Pada siklus I hasil tes peserta didik mengalami kenaikan 33.33\%, sedangkan pada siklus II meningkat 11,11\%. Jadi pada setiap siklus terdapat kenaikan hasil belajar yang signifikan. 


\section{LATAR BELAKANG}

Keterampilan membaca merupakan salah satu bentuk kegiatan untuk memperoleh pemahaman tentang sesuatu. Dengan membaca, seseorang akan memiliki wawasan yang lebih luas dan mendalam mengenai suatu topik. Oleh karena itu, peserta didik perlu memahami bacaaan. Hal itu diperlukannya di dalam kehidupan sehari-hari. Dengan demikian, kegiatan membaca tidak dapat dipisahkan dari peserta didik selama proses belajar di madrasah karena dalam proses belajar peserta didik membahas suatu topik pembelajaran mengunakan teks bacaan, baik teks non-sastra maupun sastra. Keterampilan membaca yang harus dikuasai oleh peserta didik dalam mata pelajaran bahasa Indonesia kelas IX adalah membaca pemahaman. Membaca pemahaman unsur intrinsik cerpen. Hal ini sesuai dengan Standar Kompetensi (SK) 7 yang berbunyi "Memahami wacana sastra melalui kegiatan membaca buku kumpulan cerita pendek (cerpen). Dengan Kompetensi Dasar (KD) 7.1 yang berbunyi "Menemukan tema, latar, penokohan pada cerpen-cerpen dalam satu buku kompulan cerpen”. Membaca pemahaman merupakan keterampilan yang memerlukan latihan, dan motivasi. Oleh karena itu, membaca pemahaman memerlukan model pembelajaran yang aktif dan kreatif agar peserta didik tidak jenuh selama proses pembelajaran itu berlangsung.

Hasil observasi terhadap proses pembelajaran bahasa Indonesia yang dilakukan oleh pendidik di kelas menunjukkan bahwa pendidik sudah menggunakan berbagai model pembelajaran. Pendidik juga sudah memberdayakan pemakaian berbagai media pembelajaran. Latar belakang pendidikan pendidik juga sudah sesuai dengan mata pelajaran yang diampu. Sarana prasana pembelajaran juga sudah cukup memadai. Namun, hasil pembelajaran belum mencapai ketuntasan, baik ketuntasan secara individual maupun klasikal. Hasil observasi pada peserta didik menunjukkan bahwa aktivitas proses pembelajaran membaca pemahaman unsur intrinsik cerpen belum mampu meningkatkan hasil belajar. Gejala yang tampak pada peserta didik kelas IX A4 MTsS Pondok Pesantren Dar El Hikmah Pekanbaru adalah 51,85\% peserta didik belum mampu menjelaskan dan menemukan dengan tepat unsur tema, latar dan penokohan pada cerpen. Ketika membahas unsur tersebut, peserta didik kesulitan memahami penokohan, latar suasana, tempat, dan waktu. Terutama latar yang menggunakan simbol, dan cara pengarang menyampaikan karakter tokoh di dalam teks cerpen. Hal tersebut diketahui melalui hasil tes Ulangan Harian (UH) yang dilakukan. Hasil tes itu menunjukkan bahwa peserta didik kelas IX A4 MTsS Dar El Hikmah Pekanbaru belum mampu memahami, tema, penokohan, dan latar (latar yang abstrak) cerpen. Hal itu terlihat dari 27 peserta didik kelas IX A4, yang tuntas hanya 13 orang dengan rentang nilai 75-86, dan 14 orang yang belum tuntas dengan rentang nilai 50-74. Dengan demikian, kemampuan menjelaskan, tema, penokohan, dan latar cerpen peserta didik belum mencapai target Kriteria Ketuntasan Minimum (KKM) 75 secara individual dan 85\% secara klasikal. Peserta didik kurang merespon ketika pendidik menyuruhnya membaca cerpen sebelum pembelajaran menemukan tema, penokohan, dan latar. Peserta didik kurang berminat membahas materi tersebut. Hal itu terlihat dari ekspresi kurang bersemangat saat melakukan perintah pendidik. Jika hal tersebut dibiarkan mengakibatkan proses pembelajaran tidak berjalan secara optimal, dan hasil yang diharapkan tidak akan tercapai. Akibatnya, peserta didik tidak dapat melanjutkan pelajaran pada kompetensi berikutnya. Oleh karena itu, masalah tersebut harus dicarikan solusinya.

Model pembelajaran yang dapat membuat peserta didik menjadi aktif diharapkan dapat mengatasi masalah tersebut. Pembelajaran aktif dapat membuat perhatian peserta didik selalu tertuju pada proses pembelajaran. Salah satu model pembelajaran yang membuat peserta didik aktif adalah model pembelajaran kooperatif. Model kooperatif yang dipilih adalah tipe Jigsaw. Pembelajaran kooperatif tipe Jigsaw ini merupakan model pembelajaran kooperatif yang menarik, dan dapat digunakan jika materi yang dipelajari dapat dibagi menjadi beberapa bagian. Setiap bagian dapat berdiri sendiri. Hal itu sesuai dengan materi unsur intrinsik cerpen yang dikaji pada penelitian ini. Unsur intrinsik cerpen merupakan materi yang terdiri dari beberapa bagian, yaitu tema, alur, tokoh, sudut pandang, latar, dan amanat. Setiap bagian tersebut dapat dipelajari secara terpisah.

Beberapa hasil penelitian menunjukkan bahwa model pembelajaran kooperatif tipe Jigsaw dapat meningkatkan motivasi, aktivitas, dan hasil belajar peserta didik. Hal itu dapat dilihat pada hasil 
penelitian yang dilakukan oleh Masgami (2013). Hasil penelitian Masgami menunjukkan bahwa model pembelajaran kooperatif tipe Jigsaw dapat meningkatkan kemampuan membaca pemahaman teks, yaitu memahami gagasan utama, informasi teks, fakta dan opini dalam teks serta simpulan bacaan. Berdasarkan hal tersebut, model pembelajaran kooperatif tipe Jigsaw diasumsi dapat juga memperbaiki proses, dan hasil pembelajaran membaca unsur intrinsik cerpen. Kedua materi itu mempunyai karakteristik yang sama. Perbedaannya hanya pada jenis teksnya saja, yaitu penelitian Masgami berupa teks non-sastra, sedangkan yang diteliti pada penelitian ini adalah teks sastra, yaitu cerpen.

Pelaksanaan proses pembelajaran dengan menggunakan model kooperatif tipe Jigsaw diasumsikan lebih efektif dan menarik bagi peserta didik karena langkah-langkah pembelajarannya sistematis sehingga memudahkan peserta didik memahami isi bacaan. Di samping itu, membaca untuk memahami materi di dalam model pembelajaran kooperatif tipe Jigsaw merupakan salah satu langkah yang harus dilakukan oleh peserta didik. Oleh karena itu, penggunaan model pembelajaran kooperatif tipe Jigsaw diharapkan dapat menyenangkan peserta didik terutama di dalam membaca pemahaman unsur tema, penokohan, dan latar cerpen. Model pembelajaran kooperatif Jigsaw diasumsikan dapat membuat hasil belajar peserta didik menjadi lebih baik karena mempunyai karakteristik yang unik. Peserta didik mempunyai tugas ganda, yaitu sebagai'pembelajar dan pengajar yang bertugas memahami materi, dan menjelaskan materi pada temannya. Peserta didik berperan sebagai guru bagi temannya. Dengan demikian, peserta didik akan terlatih aktif untuk mengemukakan pendapat baik secara lisan maupun tulisan. Kelebihan model pembelajaran ini adalah melibatkan seluruh peserta didik dalam proses pembelajaran. Peserta didik bekerja dalam kelompok dan peduli kepada teman. Anggota kelompok bertanggung jawab menjelaskan materi kepada anggota kelompok lainnya. Dalam hal ini, peserta didik tidak hanya menyelesaikan tugasnya, tetapi juga bertanggung jawab pada setiap anggota kelompok untuk menguasai materi yang dipelajari. Dengan demikian, peserta didik dapat menjadi tutor sebaya bagi temannya, sehingga antarpeserta didik saling memotivasi. Hal tersebut sesuai dengan karakteristik peserta didik kelas IX A4 MTs Dar El Hikmah Pekanbaru yang sudah terbiasa mengajar adik kelas, atau teman sebaya di asrama.

Model pembelajaran kooperatif tipe Jigsaw ini diharapkan dapat mengatasi masalah-masalah yang dihadapi oleh peserta didik kelas IX A4 MTsS Dar El Hikmah Pekanbaru di dalam menjelaskan tema, penokohan, dan latar cerpen. Oleh karena itu, untuk memperbaiki proses, dan hasil pembelajaran unsur intrinsik tema, penokohan, dan latar cerpen dilakukan Penelitian Tindakan Kelas (PTK). Judul penelitian ini adalah Peningkatan Hasil Belajar Unsur Intrinsik Cerpen Melalui Model Pembelajaran Kooperatif Tipe Jigsaw Siswa Kelas IX A4 MTsS Dar El Hikmah Pekanbaru.

\section{METODE}

Rancangan penelitian ini adalah Penelitian Tindakan Kelas (PTK). Penelitian dilaksanakan dengan tujuan untuk meningkatkan kemantapan rasional dari tindakan-tindakan yang dilakukan oleh pendidik sehingga hasil belajar lebih maksimal. Wardhani (2007) mengatakan PTK adalah penelitian yang dilakukan oleh pendidik di dalam kelasnya sendiri melalui refleksi diri dengan tujuan memperbaiki kinerjanya sebagai pendidik sehingga hasil belajar meningkat. Iskandar (2009) juga mengatakan bahwa PTK merupakan suatu kegiatan ilmiah yang dilakukan oleh pendidik atau dosen bersama-sama dengan tim (kolaborasi) yang bertujuan untuk memperbaiki atau meningkatkan kualitas pendidikan dan pengajaran yang diselenggarakannya. Penelitian ini dilaksanakan di dalam dua siklus. Siklus pertama terdiri dari dua kali pertemuan, dan satu kali ulangan harian, demikian juga siklus kedua, terdiri dari dua kali pertemuan, dan satu kali ulangan harian. Setiap siklus terdiri atas empat kegiatan, yaitu perencanaan, tindakan, observasi, dan refleksi. Ekawarna (2010) mengatakan tindakan pada PTK dibagi dalam empat kegiatan, yaitu (1) perencanaan, (2) tindakan, (3) observasi, dan (4) refleksi. Prosedur siklus penelitian tindakan kelas digambarkan sebagai berikut ini. 
Studi pendahuluan mengenai kemam-puan membaca pemahaman unsur tema, penokohan, dan latar cerpen peserta didik kelas IX A4 MTsS Dar El Hikmah Pekanbaru
Pelaksanaan Tindakan dan Observasi Siklus I

1. Menyajikan informasi tentang materi yang akan dipelajari.

2. Mengorganisasikan peserta didik ke dalam kelompok asal.

3. Memberikan bahan yang akan dipelajari dalam kelompok.

4. Setiap angota kelompok mempejari bagian materi yang telah ditentukan.

5. Setiap anggota kelompok membahas materi di kelompok ahli.

6. Anggota ahli kembali kekompok asal untuk menjelaskan kepada anggota kelompok asal materi yang dikuasainya.

7. Perwakilan kelompok mempresentasikan hasil keria kelom-pok ke depan kelas.

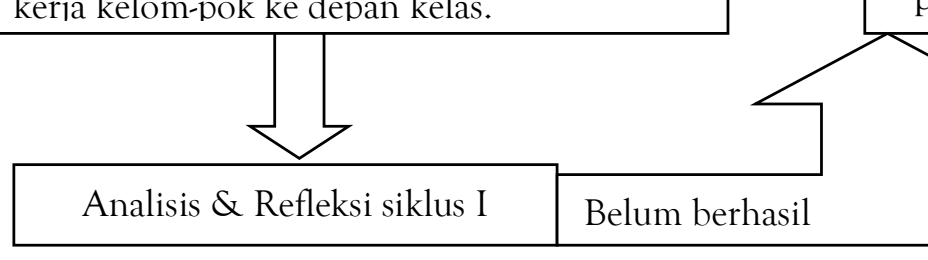

Hasil analisis dan temuan studi me-nunjukan kemampuan membaca pema-haman unsur tema, penokohan dan latar cerpen peserta didik rendah.

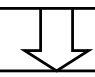

Rencana Tindakan Siklus I

1. Meningkatkan kemampuan mem-baca pemahaman unsur intrinsik novel melalui model pembelajaran kooperatif tipe Jigsaw

2. Menyusun rencana pembelajaran dengan prosedur tindakan yang akan diterapkan
Perencanaan Tindakan Siklus II

Menyusun Rencana pembelajaran dengan prosedur tindakan yang akan dilaksanakan

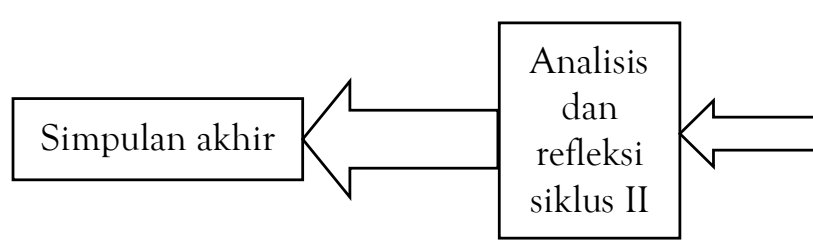

Pelaksanaan Tndakan dan Observasi Siklus II

1. Menyajikan informasi tentang materi yang akan dipelajari.

2. Mengorganisasikan siswa ke dalam kelompok asal.

3. Memberikan bahan yang akan dipelajari dalam kelompok.

4. Setiap angota kelompok mempejari bagian materi yang telah ditentukan.

5. Setiap anggota kelompok membahas materi di kelompok ahli.

6. Anggota ahli kembali kekompok asal untuk menjelaskan kepada anggota kelompok asal materi yang dikuasainya.

7. Perwakilan kelompok mempresentasikan hasil kerja kelompok ke depan kelas.

8. Memberikan tes

9. Memberikan nilai individu dan kelompok

10.Kelompok yang mencapai ketuntasan diberi penghargaan

\section{Gambar 1. Bagan Prosedur Penelitian Tindakan Kelas}

Penelitian dilakukan di Madrasah Tsanawiyah (MTs) Dar El Hikmah Pekanbaru yang dilaksanakan dari akhir Agustus sampai awal September 2017. Penelitian dilaksanakan berdasarkan hasil tes pada Ulangan Harian I, yaitu pada Kamis 28 Juli 2017. Subjek penelitian ini adalah peserta didik Kelas IX A4 MTsS Dar El Hikmah Pekanbaru yang berjenis kelamin perempuan. Peneliti memilih 
peserta didik kelas ini sebagai subjek penelitian karena kemampuan membaca pemahaman unsur intrinsik cerpen masih rendah. Data yang diperlukan untuk menjawab pertanyaan penelitian diperoleh melalui instrumen penelitian. Instrumen yang digunakan untuk mengumpulkan data penelitian adalah lembar observasi, tes, dan dokumentasi. Teknik pengumpulan data yang digunakan dalam penelitian ini adalah observasi, tes, dan catatan lapangan. Teknik observasi dan catatan lapangan untuk memperoleh data kualitatif, dan tes untuk memperoleh data kuantitatif. Data yang yang telah terkumpul kemudian didiskusikan dengan kolaborator. Moleong (2012) mengatakan bahwa pemeriksaan keabsahan data dilakukan dengan mengekpos hasil sementara, dan akhir yang diperoleh melalui diskusi dengan kolabolator. Analisis data yang digunakan dalam penelitian ini ada dua jenis, yaitu, analisis kualitatif dan kuantitatif. Analisis kualitatif digunakan untuk menganalisis proses pembelajaran, sedangkan analisis kuantitatif digunakan untuk mengana-lisis hasil belajar.

Data kualitatif yang diperoleh melalui observasi dan catatan lapangan yang berupa aktivitas pendidik dan peserta didik pada proses pembelajaran diberi skor 1, 2, 3, dan 4. Kategori penilaiannya adalah skor 4 termasuk kategori sangat baik, skor 3 termasuk kategori baik, skor 2 termasuk kategori cukup, dan skor 1 termasuk kategori kurang. Skor yang diperoleh dihitung dengan rumus yang dikemukakan Sudijono (2004).

$$
\mathrm{P}=\frac{\mathrm{F}}{\mathrm{N}} \times 100 \%
$$

Keterangan:

$F \quad=$ Frekuensi yang diperoleh

$\mathrm{N} \quad=$ Number of Cases (jumlah frekuensi/banyaknya individu)

$\mathrm{P} \quad=$ Angka persentase

$100 \%=$ Bilangan tetap

Dalam menentukan kriteria penilaian tentang hasil penelitian dilakukan pengelompokkan atas 4 kriteria penilaian, yaitu sangat baik, baik, cukup, dan kurang. Hasil penghitungan tersebut dimaknai dengan kategori sebagai berikut.

Tabel 1. Kategori Aktivitas Pendidik dan Peserta Didik

\begin{tabular}{ccc}
\hline No & Interval & Kategori \\
\hline 1 & $86-100$ & Sangat baik \\
2 & $75-85$ & Baik \\
3 & $56-74$ & Cukup \\
4 & $00-55$ & Kurang \\
\hline
\end{tabular}

Proses penyimpulan data diperoleh melalui refleksi pada setiap tahap kegiatan dalam setiap siklus. Refleksi dalam penelitian ini bertujuan untuk mengkaji hal yang telah terjadi dan belum terjadi, atau hal sudah dihasilkan dan belum dihasilkan. Hasil refleksi digunakan sebagai dasar untuk menetapkan proses rencana revisi tahap berikutnya. Analisis data kuantitatif digunakan untuk mengetahui ketuntasan hasil belajar yang diperoleh oleh peserta didik. Data ketuntasan hasil belajar tersebut diperoleh melalui tes objektif pada akhir setiap siklus. Tes ini untuk mengukur kemampuan membaca pemahaman tentang tema, penokohan, dan latar cerpen. Analisis data kuantitatif ini meliputi ketuntasan individu dan ketuntasan klasikal. Peserta didik digolongkan tuntas dalam belajar apabila mencapai kriteria ketuntasan penelitian. Kriteria Ketuntasan Penelitian (KKP) pada penelitian ini ditetapkan adalah 75. Ketuntasan belajar secara individu dihitung dengan menggunakan rumus yang dikemukakan oleh Rusdin (2007), yaitu:

dimana, KBSI adalah Ketuntasan Belajar Secara Individu

$$
\mathrm{KBSI}=\frac{\text { skor yang diperoleh siswa }}{\text { skor maksimal }} \times 100
$$

Penetapan kriteria ketuntasan klasikal penelitian pada penelitian ini adalah jika sekurangkurangnya $85 \%$ dari peserta didik telah mecapai nilai KKP, yaitu 75. Ketuntasan belajar secara klasikal dapat dihitung dengan menggunakan rumus yang diambil dari Depdiknas (2004).

$$
\text { Ketuntasan Klasikal }=\frac{\text { jumlah siswa yang tuntas }}{\text { jumlah seluruh siswa }} \times 100
$$




\section{HASIL DAN PEMBAHASAN}

\section{Dekripsi Data Awal}

Pada kegiatan awal (sebelum penelitian dilaksanakan) peserta didik terlihat kurang aktif. Aktivitas peserta didik pada proses pembelajaran awal ini kurang optimal karena sebagian besar peserta didik kurang memperhatikan pembelajaran. Walaupun pendidik sudah menggunakan model pembelajaran yang berpusat pada peserta didik, namun peserta didik tetap kurang bersemangat. Peserta didik yang aktif hanya beberapa orang saja, yaitu peserta didik yang mempunyai kemampuan tinggi, atau peserta didik yang rajin dan pintar.

Tabel 2. Rekapitulasi Hasil Tes Kegiatan Awal

\begin{tabular}{|c|c|c|c|c|c|c|c|}
\hline \multirow[b]{2}{*}{ No } & \multirow[b]{2}{*}{ Kategori } & \multirow[b]{2}{*}{ Interval Nilai } & \multirow[b]{2}{*}{ Frekuensi } & \multirow[b]{2}{*}{ Persentase } & \multicolumn{2}{|c|}{ Persentase } & \multirow[b]{2}{*}{ Rata-rata } \\
\hline & & & & & Tuntas & Tidak Tuntas & \\
\hline 1. & Sangat baik & $86-100$ & 01 & 03,37 & 48,15 & 51,85 & 66,22 \\
\hline 2. & Baik & $75-85$ & 12 & 46,15 & & & Cukup \\
\hline 3. & Cukup & $56-74$ & 06 & 22,22 & & & \\
\hline 4. & Kurang & $10-55$ & 08 & 29,62 & & & \\
\hline \multicolumn{3}{|c|}{ Juml } & 27 & 100 & & 100 & \\
\hline
\end{tabular}

Berdasarkan tabel 2 tersebut, dapat diketahui bahwa dari 27 peserta didik kelas IX A4 yang mengikuti pembelajaran unsur tema, tokoh, karakter, dan latar cerpen, yang tuntas hanya 13 orang atau 48,15\%, sedangkan yang tidak tuntas 14 orang atau 51,85\%. Rata-rata kelas hanya 66,22\% yang tergolong dalam kategori cukup. Jadi, hasil belajar peserta didik belum maksimal karena tidak sesuai dengan harapan. Oleh karena itu, peneliti melakukan perbaikan dalam pembelajaran dengan model pembelajaran kooperatif tipe Jigsaw pada siklus I dengan harapan adanya perubahan aktivitas dan hasil belajar peserta didik.

\section{Hasil Penelitian Siklus I}

Setelah pelaksanaan tindakan dengan penerapan Model Pembelajaran Kooperatif Tipe Jigsaw, pendidik melaksanakan tes untuk mengetahui hasil belajar peserta didik. Tes yang dilakukan adalah tes di akhir siklus. Bentuk tes pada penelitian ini adalah tes objektif yang berjumlah 20 soal. Soal yang menguji kemampuan memahami tema 5 buah, tokoh 5 buah, karakter 5 buah, dan latar 5 buah. Hasil tes keterampilan membaca pemahaman unsur intrinsik cerpen dapat dilihat di dalam tabel berikut ini.

Tabel 3. Rekapitulasi Hasil Tes Siklus I

\begin{tabular}{|c|c|c|c|c|c|c|c|}
\hline \multirow{2}{*}{ No. } & \multirow{2}{*}{ Kategori } & \multirow{2}{*}{ Interval Nilai } & \multirow{2}{*}{ Frekuensi } & \multirow{2}{*}{ Persentase } & \multicolumn{2}{|c|}{ Persentase } & \multirow{2}{*}{ Rata-rata } \\
\hline & & & & & Tuntas & Tidak Tuntas & \\
\hline 1. & Sangat baik & $85-100$ & 4 & 14,81 & 81,48 & 18,52 & 75 \\
\hline 2. & Baik & $75-84$ & 18 & 66,67 & & & Baik \\
\hline 3. & Cukup & $56-74$ & 3 & 11,11 & & & \\
\hline 4. & Kurang & $10-55$ & 2 & 07,41 & & & \\
\hline \multicolumn{3}{|c|}{ Jumlah } & 27 & 100 & & 100 & \\
\hline
\end{tabular}

Berdasarkan tabel 3, dapat diketahui bahwa peserta didik yang termasuk kategori sangat baik hanya 4 orang, atau 14,81\%. Peserta didik yang masuk kategori baik sebanyak 18 orang atau 66,67\%. Kategori ini mendominasi nilai peserta didik. Peserta didik yang termasuk pada kategori cukup sebanyak 3 orang, atau 11,11\%. Peserta didik yang mendapat nilai kurang sebanyak 2 orang atau 7,41\%. Jika hasil ini dibandingkan dengan hasil pada prasiklus yang diperoleh oleh peserta didik menunjukan adanya peningkatan sebanyak 36,23\%. Rata-rata kelas sudah nenunjukkan kenaikan dibanding prasiklus dari 66,54 menjadi 75. Skor tersebut termasuk dalam kategori baik. Peserta didik yang tuntas pada siklus I ini sebanyak 22 orang dengan rincian, 4 orang dengan kategori sangat baik, dan 18 orang dengan kategori baik. Jadi, dapat disimpulkan bahwa ketuntasan individu mengalami peningkatan. Walaupun ketuntasan tersebut lebih banyak pada kategarori baik daripada kategori sangat baik. Ketuntasan klasikal yang ditetapkan pada penelitian ini adalah $85 \%$ peserta didik 
memperoleh nilai minimal 75 , yaitu sesuai dengan nilai KKM yang ditetapkan oleh MGMP bahasa Indonesia MTsS Dar El Hikmah Pekanbaru.

Tabel 4. Perbandingan Ketuntasan Klasikal antara Tes Prasiklus dan Siklus I

\begin{tabular}{cccc}
\hline \multirow{2}{*}{ No. } & \multirow{2}{*}{ Keterangan } & \multicolumn{2}{c}{ Ketuntasan dalam Persentase } \\
& Tes Prasiklus & Tes Siklus I \\
\hline 1. & Peserta didik yang tuntas & 51,85 & 81,48 \\
2. & Peserta didik yang tidak tuntas & 48,15 & 18,52 \\
\hline & Jumlah & 100 & 100 \\
\hline
\end{tabular}

Berdasarkan tabel 4, dapat dilihat bahwa peserta didik yang tuntas pada tes siklus I sudah mulai meningkat bila dibanding prasiklus. Pada tes prasiklus, peserta didik yang tuntas hanya 51,85\%, sedangkan pada siklus I peserta didik sudah tuntas $81,48 \%$. Dengan demikian, terjadi peningkatan secara klasikal sebanyak 29,63\%. Peningkatan ini cukup tinggi karena nilai peserta didik pada prasiklus termasuk kategori cukup. Nilai peserta didik pada prasiklus banyak yang mendekati nilai KKM (75). Walaupun hasil secara klasikal sudah menunjukkan peningkatan yang tinggi, namun belum mencapai target $85 \%$.

Tabel 5. Hasil Tes Siklus I per Indikator yang Dinilai Secara Klasikal

\begin{tabular}{clccc}
\hline No & \multicolumn{1}{c}{ Indikator } & Jumlah Skor & Persentase & Kategori \\
\hline 1 & Menjelaskan tema cerpen & 065 & 48,15 & Kurang \\
2 & Menjelaskan tokoh cerpen & 121 & 89,63 & Sangat Baik \\
3 & Menjelaskan karakter tokoh & 093 & 68,89 & Cukup \\
4 & Menjelaskan latar cerpen & 126 & 93,33 & Sangat Baik \\
\hline
\end{tabular}

Berdasarkan tabel 5, dapat diketahui bahwa kemampuan memahami unsur tema, dan karakter peserta didik secara klasikal tergolong rendah karena dengan perolehan 48,15\% pada tema termasuk kategori kurang, dan 68,89\% pada karakter termasuk kategori cukup. Dengan demikian, pada siklus I kemampuan peserta didik secara klasikal dalam memahami latar dan tokoh tarmasuk kategori sangat baik, sedangkan kemampuan menjelaskan tema, dan karakter termasuk kategori kurang dan cukup. Jadi, penelitian perlu dilanjutkan pada siklus II untuk memperbaiki indikator tema dan karakter.

Hasil Penelitian Siklus II

Pelaksanaan tindakan dengan penerapan Model Pembelajaran Kooperatif Tipe Jigsaw yang dilaksanakan pada pertemuan pertama dan kedua dilanjutkan dengan tes untuk mengetahui hasil belajar peserta didik. Tes yang diberikan adalah tes pada akhir siklus. Bentuk tes pada penelitian ini adalah tes objektif atau pilihan ganda yang berjumlah 20 soal. Setiap indikator terdiri atas 5 soal.

Tabel 6. Hasil Tes Siklus II

\begin{tabular}{cccccccc}
\hline \multirow{2}{*}{ No. } & \multirow{2}{*}{ Kategori } & \multirow{2}{*}{ Interval Nilai } & \multirow{2}{*}{ Frekuensi } & \multirow{2}{*}{ Persentase } & \multicolumn{2}{c}{ Persentase } & \multirow{2}{*}{ Rata-rata } \\
\cline { 6 - 7 } 1. & Sangat baik & $85-100$ & 13 & 48,15 & 92,59 & 07,41 & 83,70 \\
2. & Baik & $75-84$ & 12 & 44,44 & & \\
3. & Cukup & $55-74$ & 02 & 07,41 & & \\
4. & Kurang & $10-54$ & 00 & 00,00 & & \\
\hline \multicolumn{2}{r}{ Jumlah } & 27 & 100 & \multicolumn{1}{c}{100} \\
\hline
\end{tabular}

Berdasarkan tabel 6, dapat diketahui bahwa peserta didik yang termasuk pada kategori sangat baik berjumlah 13 orang, atau 48,15\%. Peserta didik yang masuk kategori baik sebanyak 12 orang, atau 44,44\%, sedangkan peserta didik pada kategori cukup 2 orang, atau 07,41\%. Pada siklus II tidak ada satu peserta didik pun yang tergolong pada kategori kurang. Berdasarkan tabel tersebut, dapat dilihat masih ada peserta didik yang mendapat nilai cukup sebanyak 2 orang, atau 7,41\%. Namun, rata-rata kelas sudah nenunjukkan kenaikan dibanding siklus I dari 75, menjadi 83.70. Rata-rata kelas termasuk dalam kategori baik. Berdasarkan analisis pada hasil tes siklus II ini dapat diketahui bahwa ketuntasan pada aspek tema 59,26\% ada peningkatan sebanyak 11,11\%; aspek tokoh 94,81\% meningkat 5,28\%; 
karakter tokoh 84,44\% meningkat 15,55\%; dan latar 96,29\% meningkat 2,96\%. Data tersebut menunjukan bahwa peserta didik masih kurang dalam memahami tema. Pemahaman tentang karakter tokoh meningkat dengan baik, yaitu dengan peningkatan 16,16\%. Dengan demikian, dapat disimpulkan bahwa pada siklus II ini pemahaman peserta didik terhadap tema, tokoh, karakter, dan latar meningkat dengan baik. Apabila dibandingkan hasil ketuntasan individu pada tes siklus I maka dapat disimpulkan bahwa ketuntasan individu pada siklus II mengalami peningkatan yang siknifikan. Ketuntasan klasikal adalah ketuntasan yang dicapai secara klasikal. Ketuntasan klasikal yang ditetapkan pada penelitian ini adalah $85 \%$ peserta didik memperoleh nilai 75 dan di atas 75 .

Tabel 7. Perbandingan Ketuntasan Klasikal antara Tes Siklus I dan Siklus II

\begin{tabular}{cccc}
\hline \multirow{2}{*}{ No. } & \multicolumn{2}{|}{ Keterangan } & \multicolumn{2}{c}{ Ketuntasan dalam Persentase } \\
\cline { 3 - 4 } & & Tes Awal Siklus I & Tes Siklus II \\
\hline 1. & Peserta didik yang tuntas & 84,62 & 92.59 \\
2. & $\begin{array}{l}\text { Peserta didik yang tidak } \\
\text { tuntas }\end{array}$ & 15,38 & 07.41 \\
\hline \multicolumn{2}{c}{ Jumlah } & 100 & 100 \\
\hline
\end{tabular}

Berdasarkan tabel 7 di atas, dapat dilihat bahwa pada siklus II, peserta didik yang tuntas lebih banyak. Pada tes siklus I, peserta didik yang tuntas $84,62 \%$,sedangkan pada siklus II, peserta didik yang tuntas naik menjadi 92,59\%. Dengan demikian, terjadi peningkatan secara klasikal sebanyak 7,97\%. Walaupun peningkatan hasil secara klasikal 7,97\%, namun sudah mencapai target 85\%.

Tabel 8. Rekapitulasi Hasil Tes Siklus II Per Indikator yang Dinilai secara Klasikal

\begin{tabular}{clccl}
\hline No & \multicolumn{1}{c}{ Indikator } & Jumlah Skor & Persentase & \multicolumn{1}{c}{ Kategori } \\
\hline 1 & Menjelaskan tema cerpen & 80 & 59,26 & Cukup \\
2 & Menjelaskan tokoh cerpen & 128 & 94,81 & Sangat Baik \\
3 & Menjelaskan karakter tokoh & 114 & 84,44 & Baik \\
4 & Menjelaskan latar cerpen & 130 & 96,29 & Sangat Baik \\
\hline
\end{tabular}

Berdasarkan tabel 8, dapat diketahui: 1) peserta didik mampu menjelaskan tema cerpen diperoleh rata-rata secara klasikal 59,26\% dengan kategori cukup; 2) peserta didik mampu menjelaskan tokoh pada cerpen diperoleh rata-rata secara klasikal 94,81\% dengan kategori sangat baik; 3) peserta didik mampu menjelaskan karakter tokoh cerpen diperoleh rata-rata secara klasikal 84,44\% termasuk kategori baik; dan 4) Peserta didik mampu menjelaskan latar pada cerpen diperoleh rata-rata secara klasikal 96,29\% termasuk dalam kategori sangat baik. Dengan demikian, pada siklus II kemampuan peserta didik secara klasikal dalam memahami latar dan tokoh tarmasuk kategori sangat baik. Kemampuan peserta didik memahami karakter termasuk kategori baik, sedangkan kemampuan menjelaskan tema termasuk kategori cukup. Berdasarkan hal itu, dapat disimpulkan bahwa kemampuan peserta didik memahami unsur tema, tokoh, karakter, dan latar cerpen mengalami kenaikan.

Penelitian ini membuktikan bahwa model pembelajaran kooperatif tipe Jigsaw dapat meningkatkan mutu proses pembelajaran. Proses pembelajaran dikatakan berhasil jika sebagian besar peserta didik aktif secara fisik dan mental dalam kegiatan pembelajaran. Hal itu menunjukan bahwa terjadi perubahan perilaku peserta didik dari pasif menjadi aktif. Muslikah (2010) mengatakan bahwa proses pembelajaran dikatakan berhasil apabila terjadi perubahan perilaku yang positif, baik secara keseluruhan maupun sebagian pada diri peserta didik. Peningkatan proses dilihat dari hasil aktivitas pendidik dan peserta didik pada setiap siklus. Di samping itu, peningkatan proses juga dilihat dari hasil obserbasi dan catatan lapangan tentang aktivitas pendidik dan peserta didik peserta didik dalam belajar. Peningkatan proses belajar keterampilan membaca pemahaman unsur intrinsik cerpen melalui model pembelajaran koopetaratif tipe Jigsaw dapat dilihat pada pembahasan berikut ini.

Berdasarkan hasil temuan pada siklus I dan II dapat dilihat aktivitas pendidik sudah meningkat bila dibanding dengan prasiklus. Secara umum aktivitas pendidik dalam menerapkan model 
pembelajaran kooperatif tipe Jigsaw telah baik. Walaupun pada awal penerapan model pembelajaran kooperatif tipe Jigsaw ini, pendidik masih terlihat sedikit kaku. Hal itu karena pendidik belum terbiasa menerapkan model pembelajaran ini. Pada pertemuan berikutnya, pendidik sudah dapat menerapkan model pembelajaran kooperatif tipe Jigsaw dengan sangat baik. Pendidik sudah dapat melaksanakan pembelajaran sesuai dengan langka-langkah model pembelajaran kooperatif tipe Jigsaw. Model pembelajaran kooperatif tipe Jigsaw dapat membantu pendidik dalam mencapai tujuan pembelajaran membaca pemahaman unsur intrinsik cerpen. Di samping itu, model pembelajaran kooperatif tipe Jigsaw membantu pendidik dalam memberikan konsep-konsep atau pemahaman materi. Pendidik tidak perlu lagi berceramah panjang lebar untuk memberikan pemahaman kepada peserta didik tentang tema, tokoh, karakter, dan latar cerpen. Peserta didik dapat memahami unsur intrinsik cerpen tersebut melalui diskusi atau penjelasan dari temannya.

Aktivitas menyapa dan kepedulian pendidik kepada peserta didik ketika kegiatan awal berlangsung membuat suasana belajar menjadi menyenangkan. Perhatian yang ditunjukan oleh pendidik tersebut membuat peserta didik menjadi tersanjung dan senang sehinga mereka termotivasi untuk belajar. Suasana kelas yang demikian membuat pendidik menjadi bersemangat untuk mengajar. Hal tersebut sejalan dengan pendapat Hadis (2010) bahwa sikap senang yang ditunjukan oleh peserta didik dalam belajar dapat meningkatkan semangat pendidik dalam mengajar. Pada kegiatan inti, pendidik menjelaskan garis besar materi yang akan dikaji dengan bagan, dan menjelaskan langkahlangkah pembelajaran dengan diagram. Hal itu juga membuat suasana belajar menjadi menyenangkan. Kegiatan pendidik yang selalu membimbing peserta didik ketika berdiskusi membuat peserta didik menjadi mudah memahami materi yang dipelajarinya. Pendidik selalu memberi motivasi kepada peserta didik agar tidak segan untuk mengungkapkan pendapat dan tidak malu bertanya kepada pendidik atau teman. Pendidik yang telah menerapkan model pembelajaran kooperatif tipe Jigsaw yang sesuai dengan langkah-langkahnya membuat peserta didik mengerti tentang kegiatan yang akan mereka lakukan. Tindakan pendidik memberikan hadiah bagi peserta didik yang mempresentasikan hasil diskusi, dan bagi peserta didik yang dapat menjawab pertanyaan pendidik membuat peserta didik menjadi senang dan bersemangat untuk melakukan setiap perintah pendidik. Jika, proses pembelajaran sudah menyenangkan dan bersemangat tentu hasil belajar dapat dicapai dengan maksimal.

Sebelum penitian ini dilakukan, Peserta didik cenderung pasif dalam proses pembelajaran. Ditanya oleh pendidik, peserta didik jarang memberikan respon, lebih banyak diam. Setelah pelaksanaan model pembelajaran, walaupun secara bertahap, peserta didik mulai aktif. Akhirnya, peserta didik melakukan tugas pembelajaran yang diberikan oleh pendidik dengan baik. Peserta didik yang berkemampuan tinggi sudah sangat aktif mengajari peserta didik yang berkemampuan rendah, sebaliknya peserta didik yang berkemampuan rendah sudah aktif bertanya kepada peserta didik yang berkemampuan tinggi. Akhirnya, setiap peserta didik aktif saling membantu baik di kelompok asal maupun di kelompok ahli. Dengan demikian, model pembelajaran kooperatif Tipe Jigsaw dapat membantu meningkatkan aktivitas peserta didik dalam belajar. Sejalan dengan pemahaman peserta didik terhadap langkah-langkah model pembelajaran kooperatif Jigsaw yang disampaikan oleh pendidik membuat proses pembelajaran menjadi menyenangkan bagi peserta didik. Peserta didik yang sudah terbiasa dengan model pembelajaran tersebut membuat mereka tidak canggung berdiskusi dengan teman di kelompok ahli atau kelompok asal. Mereka tampak bersemangat untuk belajar. Hal itu dapat dilihat dari wajah mereka. Berdasarkan refleksi dapat diketahui bahwa proses pembelajaran yang berbentuk diskusi membuat peserta didik berani dan tidak malu-malu bertanya kepada pendidik atau teman. Peserta didik juga tidak malu untuk mengungkapkan pendapatnya. Hal itu dapat terjadi ketika pendidik mengunakan model pembelajaran sesuai dengan langkah-langkahnya. Dengan demikian, penggunaan model pembelajaran kooperatif tipe Jigsaw secara benar dalam pembelajaran membaca pemahaman unsur intrinsik cerpen dapat membuat peserta didik yang kurang aktif dalam belajar menjadi lebih aktif. Aktivitas peserta didik yang meningkat menyebabkan rasa ketergantungan di antara mereka semakin tinggi. Peserta didik yang kurang bersemangat akan merasa dibantu oleh peserta didik yang mempunyai semangat tinggi. Sikap peserta didik yang saling ketergantungan positif 
ini menimbulkan rasa kebersamaan dan kesatuan tekad untuk sukses dalam belajar, baik individu maupun kelompok.

Model pembelajaran kooperatif tipe Jigsaw juga dapat membantu meningkatkan hasil belajar peserta didik. Dari hasil refleksi setiap siklus, dapat dilihat bahwa hasil belajar peserta didik sudah ada peningkatan yang signifikan. Secara individu nilai sudah meningkat, hanya sedikit peserta didik yang mendapat nilai 75 (KKM), dan secara klasikal sudah 85\% mencapai KKM. Hasil pembahasan tersebut menunjukkan bahwa penerapan model pembelajaran kooperatif tipe Jigsaw dengan benar dan tepat sesuai dengan langkah-langkahnya dalam pembelajaran membaca pemahaman unsur tema, tokoh, karakter, dan latar dapat meningkatkan hasil belajar. Di samping itu, peserta didik akan lebih kompak dengan teman karena mereka sebuah tim yang harus selalu bekerja sama, baik dalam kelompok asal maupun dalam kelompok ahli. Hal ini sejalan dengan pendapat Budiawan (2013) mengatakan bahwa peserta didik yang terlibat dalam model pembelajaran kooperatif tipe Jigsaw memperoleh prestasi dan sikap yang lebih baik, serta bersikap lebih positif terhadap pembelajaran.

\section{SIMPULAN DAN SARAN \\ Simpulan}

Dalam pembelajaran memahami unsur intrinsik cerpen, pengunaan model pembelajaran kooperatif tipe Jigsaw dapat meningkatkan aktivitas pembelajaran pemahaman unsur intrinsik cerpen. Hal itu dapat dilihat pada aktivitas pendidik, dan peserta didik yang selalu meningkat pada setiap siklus. Pendidik dan peserta didik menunjukan keaktifan yang meningkat selama proses pembelajaran. Keantusiasan peserta didik dalam bertanya dan menjawab pertanyaan pendidik atau teman merupakan bukti keaktifan yang meningkat. Peningkatan ini dapat terjadi karena pendidik menerapkan model pembelajaran kooperatif sesuai dengan langkah-langkah pembelajaran. Pengunaan model pembelajaran kooperatif tipe Jigsaw juga dapat meningkatkan hasil pembelajaran pemahaman unsur intrinsik cerpen. Hal itu dapat dilihat dari hasil tes yang diperoleh peserta didik pada setiap siklus. Pada siklus I hasil tes peserta didik mengalami kenaikan 33.33\%, sedangkan pada siklus II meningkat $11,11 \%$. Jadi, pada setiap siklus terdapat kenaikan hasil belajar yang signifikan.

\section{Saran}

Berdasarkan simpulan, peneliti mengajukan beberapa saran kepada berbagai pihak yang terkait, yaitu: 1) pendidik bahasa Indonesia di MTsS Dar El Hikmah Pekanbaru dapat menggunakan model pembelajaran kooperatif tipe Jigsaw pada pembelajaran membaca pemahaman unsur intrinsik cerpen; 2) pendidik atau kolaborator yang ingin menerapkan model pembelajaran kooperatif tipe Jigsaw harus tegas dengan alokasi waktu supaya pembelajaran selesai sesuai waktu yang telah disediakan. Dalam penggunaan model pembelajaran kooperatif tipe Jigsaw, pendidik harus menyiapkan sarana belajar yang kondusif supaya peserta didik mudah membentuk kelompok, dan berpindah dari kelompok asal ke ke kelompok ahli, atau sebaliknya. 
26 Instructional Development Journal (IDJ), Vol. 3, No. 1, April 2020, Hal. 16-26

\section{DAFTAR RUJUKAN}

Abdul Hadis, Nurhayati B. (2010). Psikologi dalam Pendidikan. Bandung: Alfabeta.

Anas Sudijono. (2004). Pengantar Statistik Pendidikan. Jakarta: Raja Grafindo Persada.

Depdiknas. (2004). Rambu-rambu Penetapan Ketuntasan Belajar Minimum dan Analisis Hasil Pencapaian Standar Ketuntasan Belajar. Jakarta: Depdiknas.

Ekawarna. (2010). Penelitian Tindakan Kelas. Jakarta: GP Press.

IGAK Wardhani, dkk. (2007). Penelitian Tindakan Kelas, Cet. 22. Jakarta: Universitas Terbuka.

Iskandar. (2009). Penelitian Tindakan Kelas. Jakarta: Gaung Persada (GP) Press.

Lexi J. Maleong. (2012). Metodologi Penelitian Kualitatif, Rev.Ed. Bandung: Remaja Rosdakarya.

Masgami. (2011). Peningkatan Kemampuan Membaca Pemahaman Melalui Model Pembelajaran Kooperatif Tipe Jigsaw Peserta didik Kelas VII A SMP Negeri 6 Bangkinang. (Tesis). Program Pascasarjana. Universitas Negeri Padang.

Mega Budiawan. (2013). Pengaruh Model Pembelajaran Kooperatif Tipe Jigsaw dan Motivasi Belajar terhadap Prestasi Belajar Ilmu Fisiologi Olahraga. JPI (Jurnal Pendidikan Indonesia), 2(1).

Muslikah. (2010). Sukses Profesi Guru dengan Penelitian Tindakan Kelas. Yogyakarta: PT. Interprebook.

Rusdin. (2007). Metodologi Penelitian. Yogyakarta: Lanarka Pibilisher. 